\title{
WHAT IS BOOK COLLECTING? THE CASE OF STUDENT BOOK-COLLECTING CONTESTS: THEIR ORIGINS
}

BOoK-COLLECTING CONTESTS intended to encourage students to collect books have long been a fixture of college and university library programs in the United States, although they apparently are unknown elsewhere. At the initiative of the college or university library, students are invited to submit a list of books they have collected, along with an explanation of the theme and significance of their collection. After a preliminary winnowing, selected collections are judged by a panel composed of some combination of library staff, faculty, and outsiders (which may include library supporters, a local mature collector or literary figure, or a bookseller). A prize or prizes are awarded, often money, and prizewinners are afforded the opportunity to exhibit their collections in the library. The contests are managed by library staff who are otherwise responsible for rare books, manuscripts, and special collections and, increasingly, by library fund-raising operatives. Funding for the contests comes directly from the library budget, a library "Friends" support group, a local bookstore (less frequently now than earlier), or an endowment. ${ }^{1}$

1. For a review of the modus operandi of contests, see Fred C. Pfister and Bruce E. Fleury, "Student Book Collection Contests in American Colleges and Universities," College E Research Libraries 41, no. 4 (July 1980): 305-12. Articles on student book-collecting contests appeared sporadically in the library and bookselling press for some fifty years through the time of Pfister and Fleury's survey. The lack of further contributions to the literature on the subject suggests that by the 1980s the contests were firmly established in the agendas of college and university libraries. For a recent survey of the present state of student book-collecting contests that I made and posted to the online discussion group ExLibris, April 14, 2000, see $<$ http://sul2.stanford.edu/byform/mailing-lists/exlibris/2000/04/msg00118.html>. 


\section{Organized Student Book Collecting on College Campuses}

The first accessibly recorded evidence of organized book collecting by students at American colleges and universities is a series of articles by George H. Sargent published in the mid-1920s in Publishers' Weekly. ${ }^{2}$ Sargent was a bibliographical journalist who for some 15 years contributed a weekly column, "The Bibliographer," to the Boston Evening Transcript. He was a friend of the collector and bibliophilic writer A. Edward Newton (about whom much following) and compiled a bibliography of Newton's writings. ${ }^{3}$ In the earliest of the three articles in Publishers' Weekly Sargent addressed the question: "How are the book collectors of the next generation being made?" He found the answer (appropriate to the publication for which he was writing) "largely in the college bookshops," that is, bookshops in college and university towns where "thoughtful young book lovers" would congregate "to find those early editions which had been called to their notice," the young book lovers not merely coming in and asking for a book, purchasing it, and leaving, but being inspired to stay to "talk with the booksellers or among themselves about the books they found on the shelves." Sargent cited as model bookshops three that catered to students of Yale, Princeton, and Harvard Universities-the Brick Row Book Shops in New Haven, Connecticut, and Princeton, New Jersey, owned by E. Byrne Hackett, and one that emulated the Brick Row Shops, Dunster House Bookshop in Cambridge, Massachusetts. ${ }^{4}$

2. "Making the New Book Collectors," PW (Mar. 21, 1925): 1111-15; "Undergraduate Book Collecting at Yale," PW (Oct. 3, 1925): 1237-40; and "Student Book Collectors' Exhibit," PW (June 18, 1927): 2317-19. At the time, Publishers' Weekly covered not only the publishing scene but also bookselling, including the used and antiquarian trade (and bibliophily from a commercial standpoint).

3. George H. Sargent, The Writings of A. Edward Newton (Philadelphia: The Rosenbach Co., 1927).

4. About E. Byrne Hackett, the inspirational proprietor of the Brick Row shops, and the successor Brick Row shops owned by Franklin Gilliam in Austin and Houston, Texas, and in San Francisco, where the Brick Row business survives under the ownership of John Crichton, see Donald C. Dickinson, Dictionary of American Antiquarian Bookdealers (Westport, Conn.: Greenwood Pr.), 89-90. Dunster House Bookshop in Cambridge, Massachusetts, was operated by Maurice Firuski, who had worked for Hackett in New Haven. 
Sargent averred:

It seems to me that in many of our larger college towns there is an opportunity which should be grasped by some alert young man with some knowledge of book rarities and of bookselling in general. . . In any university town they would soon gather in their bookshops not only the professors and the undergraduates of the local institution, but all who are interested in rare books. This would soon create an atmosphere in which the seed of book collecting would thrive and grow, and the successful bookstore would not only have its local clientele, but a following among the alumni, who had come to know the university bookstore during their college days, and would still look to it for help in forming their collections.

In his articles Sargent reported activities aimed at actual or potential student book collectors that were more formally organized: a course taught at Harvard by George Parker Winship, then librarian of the Harry Elkins Widener Collection of rarities in the memorial Widener Library building (Winship soon to be more generally responsible for rare books and manuscripts at Harvard as curator of the Treasure Room); a course at Yale taught, under the direction of the university librarian, Andrew Keogh, by Carl Purington Rollins, printer to the university; and Yale's Elizabethan Club. He reported the fact that at Yale "some of the instructors in English literature point out to the student that it is desirable to study the text in some good old edition of a book which is under consideration in class," and at considerable length he described two annual exhibitions at Yale of books collected by students.

\section{Book Collecting by Students at Harvard}

Winship's course was the now-legendary Fine Arts 5e. As described by Boies Penrose, an eminent Philadelphian collector of travel and Americana and former student of Winship, the course treated "the book as a creation, 
as a work of art, as an important factor in its time and place ... rather than the devitalizing details of pagination and collation." Winship aimed his course at those likely to become benefactors of Harvard, situating book collecting as an elite activity. According to Penrose,

Admission was rigorously guarded by the master himself, who, in all deference, was considerable of a snob, and who always wanted to be sure that his students were properly qualified (sic). In consequence $5 e$ became known as one of the more exclusive clubs of Harvard.

The course was "fundamentally a dilettanti course," reported Sargent, not designed to make printers or booksellers or even collectors with a view to the investment involved in rare books, but to acquaint the undergraduate with some of the refinements of life and introduce them to the possibilities of a fireside relaxation for later years. . . Mr. Winship shows these boys that it is just as much fun to know the fine points of a ten-thousand-dollar book as it is to know those of a ten-thousand-dollar steeplechaser or motor car. ${ }^{6}$

Apparently Winship placed little or no stress on his students' contesting their collections with each other. (The Harvard prize for book collecting dates fairly recently, having been established by an alumnus of the 1950s.) $)^{7}$ What Winship had determined to do was to build long-

5. Boies Penrose, "George Parker Winship, 1871-1952," in Grolier 75: A Biographical Retrospective to Celebrate the Seventy-Fifth Anniversary of the Grolier Club in New York (New York: Grolier Club, 1959), 185-87. About Winship see also George Parker Winship as Librarian, Typophile, and Teacher (Cambridge: Harvard College Library, 1999), especially therein Michael B. Winship, "Fine Arts 5e: The Invention and the Aftermath," 28-40, 42-45, and Mariana S. Oller, comp., "Harvard Students in George Parker Winship's Fine Arts 5e," 4650, and Mariana S. Oller, comp., "Radcliffe Students in George Parker Winship's Fine Arts 5e," 51-53.

6. Sargent took pains to claim that bookstores, at least, were equally open to all: "The aristocracy of books creates a real democracy. Dunster House is a genuine book club for Harvard men, open to any who have a liking for books, rich and poor meeting on a perfect equality."

7. Philip Hofer Prize for Book and Art Collecting, established by Melvin R. Seiden, Harvard A.B. 1952, L.L.B. 1955. See <http://hcl.harvard.edu/houghton/programs/hoferprize.html>. 
term support for Harvard libraries. Describing Winship's term as librarian of the Widener Collection, his biographer, Walter Muir Whitehill, wrote: "As the shelves of the memorial room were already filled and nothing was to be added, Winship devoted his energies to collecting friends for the Harvard Library." ${ }^{8}$ William $\mathrm{H}$. Bond, now retired as head of the library of rare books and manuscripts at Harvard, has commented on these and other efforts at his university to cultivate in students a devotion to books:

I believe that if we can get even a few undergraduates hooked on the notion of acquiring and keeping books, in a logical and constructive way, even though they may cost little or nothing and are not strictly rare books, then later on when they can afford it they will know what the other kind of book collecting is all about and be moved to indulge in it. These are the people who will support your library when it needs it and when they have established themselves in the world they will not only have the means to do so, but they will also know what you are talking about. ${ }^{9}$

\section{Book Collecting by Students at Yale}

If Winship's course at Harvard stressed connoisseurship and clubability, the undergraduate class in bibliography at Yale, taught under the direction of Keogh by Rollins, provided students, Sargent reported, a contrastingly practical experience. Rollins delivered a set of lectures on the history of the printed book and then supervised the printing by his students of bibliographical essays or bibliographies written by students. "Each member of the class will be required to set, print, and bind a pamphlet as it was done in the eighteenth century. . . The student in bibliography will thus acquire a practical knowledge of the methods of book-making which will be of great benefit to him in his collecting."

8. Walter Muir Whitehill in Dictionary of American Biography: Supplement 5, 1951-1955 (New York: Scribner, 1977), s.v. "Winship, George Parker."

9. William H. Bond, "personal communication, 1979," quoted in Pfister and Fleury, "Student Book Collection Contests," CERL (July 1980). 
Two elements at Yale that Sargent mentioned in passing bulked large in the book-collecting culture there. The Elizabethan Club, with its own clubhouse, its own endowment, and its own collection of rarities of Elizabethan literature, had been created in 1911 by Alexander Smith Cochran, class of 1886, with the object of promoting "among its members and in the community ... a larger appreciation of literature and the arts of social intercourse founded upon such appreciation." The club continues to this day as a bibliophilic center in the New Haven community, membership by invitation. ${ }^{10}$ Of the instructors in English literature who drew the attention of their students to early editions, Chauncey Brewster Tinker was the most prominent. Tinker, who, beginning in 1931 when Sterling Library opened, also filled the post of Keeper of Rare Books, influenced generations of students through his long tenure at Yale and became a revered figure. He brought books and manuscripts from his personal collection to his undergraduate classes and graduate seminars, reading from them and allowing his students to use them. ${ }^{11}$

The culmination of the Yale undergraduate class in bibliography was an exhibition of books owned by members of the class. As beginning collectors, the Yale undergraduates displayed both a high degree of enthusiasm and a high degree of polish. Sargent reported that 35 undergraduate collectors offered some 400 books for exhibition in 1925 , of which there was room enough for only 260 . The exhibitors demonstrated particular interest in "beautiful books" (illustrated books, fine printing, and fine bindings), the works of modern English writers (nineteenth- and twentieth-century literature), and "collectors'" books (those in fine condition, those demonstrating collectors'

\footnotetext{
10. Stephen Parks, The Elizabethan Club of Yale University and Its Library (New Haven, Conn.: Yale Univ. Pr., 1986).

11. Marjorie G. Wynne, "Chauncey Brewster Tinker, 22 October 1876-17 March 1963," in Grolier 2000: A Further Grolier Club Biographical Retrospective in Celebration of the Millennium 2000 (New York: Grolier Club, 2000), 379-82.
} 
"points," and association copies). Included in the exhibition of 1925 were, for example, a souvenir of a production in 1902 of Acis and Galatea with illustrations by Gordon Craig of the costumes he designed for the production, which Craig had presented to his mother, Ellen Terry, and a spectacular manuscript, part of the original copy of Yale president Timothy Dwight's Travels in New England and New York, in the hands of a series of undergraduates whom Dwight employed as amanuenses because of his failing eyesight. Sargent reported that the exhibition in 1927 included illuminated manuscripts, specimens of early and fine printing (a leaf of the Gutenberg Bible "of course"), English literature of the eighteenth and nineteenth centuries, some American literature, illustrated books, and drawings and autograph letters of writers.

These exhibitions were not posed as competitions, no prize being offered. The present prize competition at Yale, in which the Adrian Van Sinderen prizes are awarded, dates-as Harvard's-fairly recently, having been established in 1957. As at Harvard, these efforts at nourishing a love for books-the prize competitions and the earlier exhibitions as well as the professorial efforts of Tinker and others-have been of benefit to Yale. Nicholas Basbanes in his recent survey of book collecting notes that winners of the Van Sinderen Prize have included at least two booksellers of national reputation and a noted collector of sixteenthcentury books, and Marjorie Wynne in her sketch of Tinker notes other prominent collectors and authors whom Tinker inspired. Most of these persons have been extraordinarily faithful to Yale and its libraries, contributing books and papers and lending support, in financial form and otherwise. ${ }^{12}$

12. Nicholas Basbanes, in his A Gentle Madness: Bibliophiles, Bibliomanes, and the Eternal Passion for Books (New York: Henry Holt, 1995), 293, erroneously states that "the Adrian Van Sinderen Award is the oldest undergraduate book-collecting competition in the United States" and adds (dubiously, such a quality being unmeasurable) that it is "by far the most prestigious." 


\section{Book Collecting by Students at Princeton}

Exhibitions of books collected by students at Princeton can be traced back to $1922 .{ }^{13}$ Looking back to that year, presumably in 1923, George

M. Peck, curator of special collections, proposed the next exhibition:

In the spring of 1922 the Library held an exhibition of rare books, first editions, and manuscripts collected by the students of the University. The interest created warrants our attempting another exhibition. I will be glad to take charge of the material and would like the students who are interested to bring me any manuscript, rare book, or first edition that they are willing to have exhibited.

Accompanying Peck's announcement in the files (suggesting that all the documents are contemporaneous) are two notes undated (but one presumably from 1923 and the other from 1924) from the Brick Row Book Shop of Princeton that forward to Peck, in one case, the names of "undergraduates on our books [who] would probably be interested in your rare book exhibition" and, in the other case, "undergraduates interested in book collecting." The implication is of course that the Brick Row Book Shop of Princeton had succeeded in cultivating student book collectors and that students probably recognized the shop as a locus of bibliophily more readily than they did the library.

The real beginning of the student book-collecting contest at Princeton as a competition that awarded a prize (as distinct from book-collecting exhibitions in connection with which no prize was offered) dates from 1939. On June 23, Lawrance Thompson, curator of rare books, wrote to Morris L. Parrish, class of 1888, the fastidious collector of Victorian literature and benefactor of Princeton: 
We are doing our best to build up book-collecting interest among the undergraduates. It was at low-ebb last year, for when we held our undergraduate exhibition of student collections we had only three men who participated. This year we offered $\$ 50$ in prizes (a first, a second, and two honorable mentions) ... and we had twenty-two boys who showed.

The intent of the event was educational. Thompson continued:

Each man brought only ten books-his ten most highly prized-to represent his reading and collecting interests. Then each man sat down with three judges and made a "defence" of his books, one at a time. The judges discussed his collecting interests, edition-points, bindings, condition, business of writing in books, kinds of bookplates that were good and bad, etc. etc. The other men were permitted to sit around and listen to the judges and to the competitors. So when the awards were made, they had been subjected to a pretty good "course of sprouts" in library-building and in collecting.

An innovation involving members of the faculty was planned for the next year.

Next year, we are going to add a new feature, by having about a half-dozen professors submit units of ten books each, and after the student exhibition, let three student-judges sit down and listen to the explanations of the professors, while other students form an audience. It will begin in fun, but I think it will be an educational kind of fun.

By 1942, Princeton was conducting its "20th annual exhibition of book collections made by Princeton students," with the Princeton University Store funding the prize awards. ${ }^{14}$ In 1954 , the library support group, 
Friends of the Princeton University Library, assumed the funding of the awards.

Meanwhile, an event of major significance to bibliophily in Princeton had occurred: the university had welcomed Elmer Adler into its fold. ${ }^{15}$ Adler, whose coming to Princeton was first envisioned by Lawrance Thompson and was effected by the insistence and financial support of the Friends of the Library, was starting a third career in Princeton. As a young man he had entered the family clothing business in Rochester, "when he was fired from Andover, his fourth school,"16 eventually taking charge of the sales promotion and advertising of the firm, the handsomeness of which soon drew attention. He built a collection of prints and books, which he loved to share with a boys' club he started for that purpose at the local Jewish Young Men's Association, and in 1920 he organized an exhibition on the history of printing at the Memorial Art Gallery. In 1922 Adler went to New York "to lose his fortune." In New York he directed a fine printing plant, Pynson Printers, that pretended to be a commercial operation but never made money. In New York, he nurtured his library of historical examples of printing and an exhibition gallery therefor, and he published The Colophon, the Quarterly for Booklovers.

In 1940 Adler moved with his collection to Princeton. There, he established a center for both the study and the enjoyment of the graphic arts, producing exhibitions, offering his own lectures and lectures by other speakers distinguished in the graphic arts, conducting seminars for undergraduates (which were extracurricular but so enthusiastically received that they attracted the participation of faculty and towns-

15. About Adler see Elmer Adler in the World of Books: Reminiscences, ed. Paul A. Bennett (1964), issued with four different imprints, "The Princeton University Library," "New York: The Typophiles," "New York: The Grolier Club," and "La Casa del Libro, San Juan, P.R." See also A Memorial Service for Elmer Adler Held January 26, 1962, Temple B'rith Kodesh, Rochester, New York (Rochester, N.Y.: Press of the Good Mountain, 1964).

16. Frederick B. Adams Jr., "The Four Lives of Elmer Adler," in Elmer Adler in the World of Books, 1-10, from which this quotation and the following ones are drawn. 
people), operating a print-lending club (having been "horrified by the banality of decoration in the students' rooms"), and carrying on the student book-collecting contest. ${ }^{17}$ After his death in 1962, his estate endowed the then-redesignated Elmer Adler Book Collecting Contest. ${ }^{18}$

\section{The Book-Collecting Boom of the 1920s}

The early glimmers of student book-collecting contests were part of the boom in book collecting that flourished in the 1920s. New but inevitably inexperienced and often undiscriminating collectors entered upon book collecting, fashions like collecting the works of contemporary authors reigned, formulaic aids such as standard lists of collectible books and handbooks differentiating among bibliographical peculiarities were overly respected, and prices rose in a climate of speculation. In a standard account John Carter characterized the period as follows:

The authors on whom attention was mostly concentrated were all well-established in the esteem of the reading public, and collectors dully, obediently and every year more expensively followed suit. It was of course a period of generally rising prices, especially in America. Book-collecting had for various reasons come to be regarded as 'the done thing' among many persons desirous of being thought cultured. And without the restraints which discrimination, connoisseurship and individuality of taste impose on true bibliophily, the result was an undignified stampede. ${ }^{19}$

Bibliophily and specifically book collecting of that period had no stronger or more effective champion than A. Edward Newton-Philadelphian,

17. According to Adams, "Four Lives," 7, Adler "established an annual undergraduate bookcollecting contest," but, in fact of course, what Adler did was add his own considerable weight to the series of contests that George Peck had initiated. Starting at some point during the $1940 \mathrm{~s}$ the contests were held within Adler's precincts, at 36 University Place, rather than in the library, and they continued there until after 1948 when the new Firestone Library opened.

18. Gillett G. Griffin, "Undergraduate Book Collecting Contest," Princeton University Library Chronicle, 24, no. 2 (winter 1963): 144-45.

19. John Carter, Taste and Technique in Book-Collecting: A Study of Recent Developments in Great Britain and the United States (New York: R. R. Bowker, 1948), 39. 
manufacturer of electrical equipment, and collector especially of English literature of the sixteenth through the nineteenth centuries, particularly the writings of Samuel Johnson and other eighteenth-century authors. Newton cultivated friendships among fellow bookmen and bookwomen, not the least with fellow Johnsonians Tinker of Yale and Charles Grosvenor Osgood of Princeton. An anglophile nonpareil, he disported himself in boldly checked suits and delighted in bookish conversations engendered at tea parties held at his suburban property, Oak Knoll, where tea was poured from a teapot once owned by Dr. Johnson. Above all, Newton practiced what he called "this book-collecting game" with joy and gusto. He collected books about which a good story could be toldthe motto of his book-plate is the Johnsonian epigram from Boswell, "Sir, the biographical part of literature is what I love most." He enjoyed distributing among his friends little blue-bound pamphlets that he wrote on bookish subjects and had printed, and he transmitted his enthusiasms to a wide audience eager to enjoy book collecting through lectures and 
essays about his books that were published in taste-confirming magazines like Atlantic Monthly _-"The Amenities of Book-Collecting" for one, which were subsequently compiled into a half-dozen or so volumes.

Even at the time when Newton himself circulated in the book world, many found repellant his rambling effusions and personal posturing, as many now do, but unquestionably he recruited a public to book collecting. Thomas R. Adams, who early knew about Newton through family connections and who remembers being introduced to him at the age of eleven, commented:

No one has ever called Newton a profound bookman, but he was the most complete bookman of his time. He was a reader of books, he was a lover of books, he was a buyer of books, he was a collector of books, he was a writer of books, he was a publisher of books, he was a talker of books, he was a builder of libraries, and most of all he was a seller of books. He sold them to the American people. ${ }^{20}$

Millicent Sowerby remarked, in connection with reporting Newton's pleasure at receiving George Sargent's bibliography of his works, that Newton well deserved this tribute "for his books on rare-book collecting had been a great help to the trade." 21

\section{Book Collecting in the 1930s and Beyond}

The collapse of the high-flying antiquarian book market that ensued from the crash of the stock market in October 1929 left dealers with

20. For Adams's discerning sketch of Newton, see Grolier 75 (1959), 130-32.

21. E. Millicent Sowerby, Rare People and Rare Books (London: Constable, 1967), 200. According to Sowerby, the well-starched Englishwoman who was cataloguer to the famous bookseller A. S. W. Rosenbach, Newton "acted as though he were a reincarnation of the great Dr. Johnson" and often was intolerant of her because, she once explained, "I really am English." (ibid.) Newton's collection of rare books was sold posthumously at auction in 1941, when many of them were revealed to be in shockingly poor condition. Sowerby's account (ibid., 201-2) of the opening night of the sale, depicting an atmosphere that was simultaneously celebratory and mournful, is a gem of bibliophilic writing. 
overvalued, unsalable stock, left collectors with at least paper losses on the value of their collections, and led to the exit of many collectors from the market. After the dust of the crash had settled, however, the response of the book world was eminently rational-promotional efforts were intensified. "The year 1930" was, as Carter recounted, "a time, if ever there was one, for all good men to come to the aid of the party." One concrete result of these efforts was the publication in 1934 of a book aimed directly at collectors and potential collectors, New Paths in Book-Collecting, with contributions by both collectors and members of the rare book trade. ${ }^{22}$ Carter pointed out that this publication "was only one instance of the responsible part taken . . by professional booksellers, not merely through their practical influence exerted in the course of business, but also by their contributions to bibliophilic literature and propaganda, in the formation and exposition of theory, of policy and of practice in the book-collecting world." He adduced, in the world of bibliophily and book collecting at that time, the presence of a "general propagandistic movement." 23

Other responses by the antiquarian book community, less ostensibly promotional, were the commencement in 1930 of two bibliophilic periodicals with contributions again by both collectors and members of the rare book trade, in England The Book-Collector's Quarterly and in America The Colophon, presided over by Elmer Adler. A member of the magazine's editorial board, Frederick B. Adams Jr. wrote that The Colophon was "conceived in the lush days of 1928 and 1929 as a boon to booklovers and an adventure in enthusiasm, it was born in 1930 and died uncompromised in 1940." ${ }^{24}$ According to the prospectus of the

22. Edited by John Carter. Published in London by Constable \& Co. and in New York by Charles Scribner's Sons. The new paths were detective fiction, musical first editions, war books, and so on.

23. Carter, Taste and Technique in Book-Collecting, 79.

24. Frederick B. Adams Jr., Elmer Adler, Apostle of Good Taste: An Address Delivered January 21, 1941, on the Occasion of an Exhibition of the Work of the Pynson Printers (New York: privately printed for The Typophiles, 1942), 13. 
magazine, the intended audience was "the reader . . [who] already collects books and knows why." And, as the prospectus continued, "Its appeal, therefore, cannot be elementary, nor will it be a vehicle of collecting propaganda." ${ }^{25}$ If its content was not propagandistic, the effect of the magazine, as a result of its high editorial, artistic, and typographic standards, was unquestionably to promote bibliophilism.

Within the ambience of the "general propagandistic movement" of the 1930s, three occurrences came to pass that touched materially on student book-collecting contests-one effected personally by A. Edward Newton, one effected conjointly by interests in the book trades, and one sponsored by The Colophon.

In 1931 Newton published an article in Atlantic Monthly in which he announced his endowment of a prize for student book collecting at Swarthmore College, urging others to endow such prizes elsewhere. ${ }^{26}$ Newton recounted that Robert Spiller, then a professor of English at Swarthmore, had prevailed on him to receive a group of "ten or a dozen students, boys and girls, to see his books." Uncharacteristically, Newton had hesitated to agree, he claimed, knowing that "pretty much every book one shows to a young student" must be "explained ... if he is to carry away with him any proper idea of what a collection of first editions really means" and that "one can make such an explanation once, or even ten times, with a certain amount of enthusiasm; after that it becomes a task." But the students, "young men and maidens," once arrived and partaking of his books and explanations, impressed Newton "with their keenness and intelligence." In fact, "one of them, a mere slip of a girl, had stood me up and put me through an oral examination on Printers, 1935), 5-16.

26. A. Edward Newton, "Books of One's Own," Atlantic Monthly (Oct. 1931): 443-51. Reprinted (revised) as "On Forming a Library" in his End Papers: Literary Recreations (Boston: Little Brown, 1933), 13-35. 
Boswell's Life of Johnson from which it was difficult to escape with credit."

Equally amazed and pleased, Newton asked Spiller, "How on earth did you arouse in these young people such an interest in books?" Spiller explained that for several years a small sum of money had been donated to the college to be awarded as a prize for the best student collection of books. Spiller added though that with the recent death of the donor, the prize award was in danger of lapsing. "This Swarthmore idea," Newton reported, "appealed to me as I talked it over with Spiller, so I then and there offered to carry on the plan, taking care that the scheme should not lapse at my death." Thus Newton created the first endowed prize for student book collecting at an American college or university. It continues today as the "A. Edward Newton Library Prize endowed by A. Edward Newton, to make permanent the Library Prize first established by W. W. Thayer."27

The "Swarthmore idea," Newton stated,

can be made of great and lasting benefit and delight to those who in the formative years of their life learn the joy of having a collection of books in a room of one's own. ${ }^{28}$ And there is no college or university so poor as not to have a man, or group of men, who will give every year fifty or a hundred dollars for the purpose indicated. . . . God forbid that I should say a word against a public library, but nothing will take the place of a rack or a shelf full of books by one's own chair. ... Everyone's shelf will contain different books, and the books which give one joy as a boy may not delight a man, but the pleasure of reading continues.

Taking the idea with him, Newton mentioned it to "an important New York publisher at dinner." 
He was strong for it, wanted me to write a little book about it which he would publish, but I wanted a wider spreading of the idea. It is for that reason that I send this paper to the Atlantic. That a publisher would be taken by the idea is not remarkable: the number of book buyers would be increased by the general acceptance of the scheme. Publishers have to think of sales. But I am not a publisher; I am thinking only of the pleasure with which a man in after years will point to the collection of books made when he was a student at college. "Those books," he may say, "established in me the love of reading, and the love of reading has been the joy and solace of my life." And so this paper is, in a way, an advertisement, - an advertisement of an idea.

The person who most publicly next, in 1934, took up Newton's idea was, rather than a publisher, a bookseller-E. S. McCawley, of Haverford, Pennsylvania, then president of the American Booksellers' Association. In an article in Publishers' Weekly McCawley reported that, stimulated by Newton, booksellers had funded prizes for student book collecting-the Hampshire Bookshop of Northampton, Massachusetts, at Smith; Dawson's Bookshop of Los Angeles at the University of California, Los Angeles; and the Hathaway House Bookshop in Wellesley, Massachusetts, at Wellesley College; that an anonymous donor had donated prize money to the University of California, Berkeley, and that the president of the Franklin Railway Supply Company had subvened a prize at Purdue University. ${ }^{29}$

McCawley announced that a coordinating trade group of which he was a member, the Joint Board of Publishers and Booksellers, had taken "great interest in the idea" and had appointed a committee, of which he was a member, "to investigate what has been done and to put these facts before booksellers, publishers, and educational institutions in order to obtain 
wider attention to the building of libraries by students during their undergraduate years." He envisioned elevating the idea from the local to the national level. "The Joint Board," he continued, "feels that there might even be a sufficient response from schools and colleges throughout the country so that a national award might be made for the best undergraduate library selected from the winners of local or sectional awards." McCawley and the Joint Board advocated concerted promotion of the idea:

The Joint Board urges booksellers in college towns to call the attention of members of the faculty and college librarians to the plan... Speaking as President of the American Booksellers' Association and a member of the Joint Board of Publishers and Booksellers, I feel that in promotional efforts of this nature lies a real progress for booksellers and publishers in gaining lifelong friends for both branches of the industry, as well as a purely altruistic effort to widen cultural and literary horizons for the men and women of America during their college years. 
This advocacy assumed practical form in 1935 with the issuance of a pamphlet Prize Awards for Student Libraries. The pamphlet demonstrated that efforts had been coordinated among publishers, booksellers, librarians, the book trade press, and a library-oriented foundation. It had been produced by a committee consisting of Frederic G. Melcher, president of the book trade and library publisher, R. R. Bowker Company, Christopher Morley, writer, editor, and literary journalist, Charles E. Rush, associate librarian at Yale, and McCawley. Further, it had been funded by a grant from the Carnegie Corporation of New York and was distributed by the Library Journal, a Bowker publication. Meant to "answer practical questions relative to the establishment of such prizes," the pamphlet comprised an inspirational essay by Morley; a review of existing prize competitions by McCawley, in which he named prize competitions established at a dozen more institutions than he had named in his article of the previous year in Publishers' Weekly; an announcement of a prize competition offered as a model (that used at Connecticut College, the prize there having been donated by Rush); and a bibliography of published references to contests. ${ }^{30}$

Prize Awards for Student Libraries was an effective promotional instrument. In 1937 Lawrenceville School in New Jersey was reported to be the first preparatory school to conduct a student book-collecting contest. ${ }^{31}$ During the 1940 s the pamphlet was dispatched from the

30. The title of Morley's piece, "The Eumenides of Book-Collecting," playing on Newton's title, "The Amenities of Book-Collecting," indicates of course the renown that Newton's essay enjoyed as book-collecting propaganda. (Consider also Chauncey Brewster Tinker's "The Asperities of Book-Collecting," Yale Review, 9 [1919]: 207-9.) The essay by Morley, an alumnus of Haverford College, was originally published in Haverfordian, November 1934, having been written to celebrate the creation of the Logan Pearsall Smith Prize for book collecting, which Morley had helped organize (named for the distinguished essayist, philologist, litterateur, ex-Haverfordian-then living). Morley mentioned in his essay the neighboring bookseller, "Mr. McCawley, a true paramour of print." The Logan Pearsall Smith prize was reported to me as now defunct by the Haverford Librarian Robert Kieft (rkeift@haverford.edu to dfarren@concentric.net, "Re: Student book collecting contest," Feb. 19, 2001). In his article in $P W$, McCawley stated that "Mr. Newton has himself recently established a Newton Prize Award at Haverford College," erroneously implying that it was another Newton prize for book collecting. Surviving at Haverford is a Newton Prize in English Literature awarded on the basis of final honors in English.

31. William E. Harris, "Student Libraries and Their Awards," Horn Book 13, no. 2 (Mar.-Apr. 1937): 71-74. 
Princeton librarian's office to answer inquiries about contests. ${ }^{32}$ As late as 1951 the competition at the University of Kentucky was reported as following "rather closely the principles established in 1934" by the Joint Board. ${ }^{33}$

A late realization of McCawley's vision of a national student bookcollecting contest was the Amy Loveman Award competition conducted from the early 1960s to the early 1970s by the Women's National Book Association with support from Saturday Review and the Book-of-the-Month Club. The competition was named after a widely known and respected editor of Saturday Review and functionary of the Book-of-the-Month Club, a familiar of the publishing and bookselling industries, who "was particularly interested in broadening the horizons of young people by introducing them to the universe of books and ideas." 34 The competition was open to college and university seniors who were nominated to compete for the award by a Campus Library Award committee, normally on the basis of winning a local competition. The prize was $\$ 1,000 .^{35}$

The third occurrence of the "general propagandistic movement" of the 1930s was the sponsoring of a book-collecting contest by The Colophon. ${ }^{36}$ Good cheer was the keynote of this contest. In the winter issue of 1938, Frederick B. Adams Jr. announced in "The Crow's Nest," the regularly appearing column he conducted:

32. Memorandum, Julian P. Boyd to Julie Hudson, "Undergraduate Book Collecting Contest," May 7, 1940.

33. William E. Schulenberg, "A Student Library Contest-For Better Reading," Wilson Library Bulletin 26, no. 2 (Oct. 1951): 168, 186.

34. "Amy Loveman \$1,000 Student Collecting Award," AB (Oct. 23, 1961): 1451-52.

35. On the Amy Loveman Award see also Pfister and Fleury, "Student Book Collection Contests," CERL (July 1980).

36. The contest was a creature of the second and third incarnations of The Colophon. The original series ran from 1930 to 1935, a new series from 1935 to 1938, and a New Graphic Series from 1939 to 1940 , all under much the same boards of editors. The original series is covered in Winterich, "'... In the Original Twenty Parts'," in Index ... 1930-1935 (1935), 516, and Dean H. Keller presents the publishing details of the later series in a note, "Format and Editorial Matters," in his An Index to The Colophon, New Series, The Colophon, New Graphic Series, and The New Colophon (Metuchen, N.J.: Scarecrow Pr., 1968), 135-39. 
The editors of The Colophon, poor gentle fanciful souls that we are, believe that among the undergraduates in the 600-odd colleges of the United States and Canada, there must be one who has a small collection of books sufficiently important to inspire an article that we would all enjoy reading. Almost any bibliolatrous angle is acceptable, except literary criticism-The Colophon never thought it would be quite cricket to enter into competition with the critical journals that already crowd the field. A friend has offered a prize of $\$ 50$ in cash as the proper bait. Manuscripts must be received at the offices of The Colophon not later than August 31, in order that the prizewinning paper may be published in Number 4 of Volume III, and so bring the year to a happy ending. ${ }^{37}$

A reminder ran in the spring 1938 issue: "No hope abandon, ye who enter here!" it ended. And in the autumn 1938 issue the winners were announced:

We did hope to unearth a few people touched with genuine bibliomania, and our success was greater than we had hoped. We had to award a second prize as well as a first, and we are printing the two winning articles in this issue because we expect you'll like them as much as we did. There were several other papers which, in the face of less severe competition, would have carried away honors, and it is a real disappointment that we do not have the space to print them. ${ }^{38}$

The winning articles were, first prize, "Collecting Civil War Novels," by Richard H. Wilmer Jr., an undergraduate at Yale, and, second prize, "Dusty Shelves and Irishmen," by Elizabeth Ridgway, who had been graduated in June by Antioch College, about her love for books and second-hand bookshops and about her books, chiefly Irish literature and works on Ireland and the Irish. ${ }^{39}$ 
Adams announced in the Crow's Nest column that ran in March 1939 a second contest and inserted a reminder in the June issue. ${ }^{40}$ The winner of the second contest was announced in the September issue, and the winning article ran in the issue of February 1940. The winning article, "A Bibliophile in Rompers" by Bernard Lebovit, a student in the printing department of the Carnegie Institute of Technology, recounted "how books led him from a membership in the Bayonne High School Philosophy and Chess Club through the Fourth Avenue book dealers to his present professional interest in printing craftsmanship." ${ }^{41}$ No more was heard of a Colophon book-collecting contest because The Colophon expired with the issue in which the winning essay of the second contest ran. ${ }^{42}$

Meanwhile, what was the thinking of college and university library administrators about student book-collecting contests? If Guy Lyle's thinking, as expressed in an article written from the perspective of the 1930s and published in 1941, may be taken as indicative, their interest in student book collecting stemmed from their worries about the citizenry's lack of commitment to reading. ${ }^{43}$ "It is disconcerting," Lyle wrote, "to learn that reading in the average American home has been losing in its race with other leisure-time activities. ... In competition with newspapers and magazine reading, the movie, the radio, golf, bridge, and the automobile, books are apparently hardly in the running." The issue was, of course, that reading ability provides "a basis

\footnotetext{
40. The Colophon, new graphic series, 1.1 (Mar. 1939): 101, and new graphic series, 1.2 (June 1939): 99.

41. The Colophon, new graphic series, 1.3 (Sept. 1939): 86, and new graphic series, 1.4 (Feb. 1940), [13]-[16].

42. The Colophon to be revived briefly as The New Colophon, 1948-1950.

43. Guy R. Lyle, "College Libraries Encourage Reading," Journal of Higher Education 12, no. 4 (Apr. 1941): 191-97. The thinking of Lyle, during the 1930s librarian of Antioch College and of the Women's College of the University of North Carolina, Greensboro (later librarian of Louisiana State University and Emory University), influenced other academic librarians through his teaching of librarianship at Emory University and elsewhere and especially through his textbook, The Administration of the College Library (New York: H. W. Wilson, first ed., 1944; 4th ed., 1974).
} 
for thinking independently on many matters of importance." College and university librarians were doing their best to encourage reading, and "fortunately ... in the colleges, at least, are to be seen unmistakable signs that the undergraduate today is making more extensive use of his college library than his elder brother did a decade ago."

What means were academic librarians using to encourage reading? One of them was "the establishment of student prize awards for private libraries ... as an inducement to developing genuine interest in and enthusiasm for books" (the other means were providing books for "cultural and recreational reading" in "browsing rooms," sales of library duplicates, and collections in dormitories and fraternity and sorority houses). As for the book-collecting prize competition specifically: "The number of entrants is never very large, but the student body is usually enthusiastic in its attendance and criticism as to the respective merits of the collections submitted, and the final exhibit of the prize collection ... brings forth many a wistful glance on the part of would-be owners." 44

\section{Conclusion}

Thus we see that the tale of student book collecting and of prize contests for student book collecting hangs from a rope braided of several strands including:

* connoisseurship, a refining, elite activity worthy of emulation (exemplified by Winship, the exhibits at Yale of student collections, and the Elizabethan Club);

* professorial generosity (exemplified by Tinker and Spiller);

* library-building for the future (as at Harvard and Yale);

* pure love of books and reading (embodied by Newton);

44. Lyle's article of 1941 was the basis for his chapter on "The Encouragement of Reading" in his textbook, where in the first edition his treatment of the student book-collecting contest was illustrated with a model entry form. Later editions of Administration of the College Library devoted progressively less space to student book-collecting contests. 
* commercial, bookselling motives (exemplified by Hackett, McCawley, et al.);

* aesthetic impulses (exemplified by Adler);

* the educational impulse to stimulate a lifelong habit of reading as a basis of responsible citizenship.

Are student book-collecting contests a uniquely American phenomenon? A recent survey that I conducted of the present state of student book-collecting contests caused me to wonder. I appealed widely in the English-speaking world for information, and although I promptly received information about existing contests in the United States, I received only one response from Canada and none from Great Britain. In fact, a well-placed trans-Atlantic correspondent confessed that he had never heard of such a thing. If student book-collecting contests are a uniquely American phenomenon, why? Because of Newton's initiativethe hero in history? Because of a unique combination of educational and 
commercial motives-social and economic forces? Because of a peculiarly American comfort with the marriage of commercial impulses, aesthetic impulses, and educational principle-national character? Do the origins of the contests tell us?

\section{Acknowledgements}

This article could not have been written without the documentary support and continuing interest and encouragement that Stephen Ferguson of Princeton University generously provided, for which I am very grateful. Other persons to whom I am grateful for assistance include Thomas R. Adams, Brown University; Allen Ahearn, Quill E Brush; Gabriel Austin, New York; Terry Belanger, University of Virginia; Lisa Browar, Co-editor, RBM; Robert Kieft, Haverford College; Mary Ann O'Brian Malkin, New York; Robert S. Martin, Texas Woman's University; Karen Nipps, Harvard University; Stephen Parks, Yale University; Anna Lee Pauls, Princeton University; Diana Franzusoff Peterson, Haverford College; Robert RulonMiller, Jr., Saint Paul, Minnesota; Peggy Seiden, Swarthmore College; Margaret Sherry, Princeton University; Michael Smallman, The Queen's University of Belfast; Ushi Tandon, Swarthmore College; Willis Van Devanter, Poolesville, Maryland; Dale Walker, University of Chicago; and Thomas M. Whitehead, Temple University. Any errors of fact or interpretation are of course mine alone. 